\title{
Oxidizable fractions of soil organic carbon in Caatinga forest submitted to different forest managements
}

\author{
Suellen Gomes Monteiro Batista ${ }^{1}$ Patrícia Anjos Bittencourt Barreto-Garcia ${ }^{2^{*}}$ \\ Alessandro de Paula $^{2}$ Divino Levi Miguel ${ }^{2}$ Willyan Charles Amaral Batista ${ }^{1}$ \\ ${ }^{1}$ Universidade Estadual do Sudoeste da Bahia (UESB), Vitória da Conquista, BA, Brasil. \\ ${ }^{2}$ Departamento de Engenharia Agrícola e Solos, Universidade Estadual do Sudoeste da Bahia (UESB), 45083-900, Vitória da Conquista, BA, \\ Brasil. E-mail: patriciabarreto@uesb.edu.br. "Corresponding author.
}

\begin{abstract}
One of the main alternatives for the rational exploitation of the Caatinga biome's natural resources is sustainable forest management. Soil organic carbon (SOC) and its fractions can be used to evaluate the conservation status of forest ecosystems after anthropic interventions. Therefore, the objective of this study was to evaluate the short-term effect of different forest management practices on the distribution of SOC fractions in the Caatinga area located in Contendas do Sincorá National Forest (BA). Three forest management practices (clear cutting, selective cutting by diameter and selective cutting by species) were evaluated, using the unmanaged Caatinga as a control. Soil samples were collected at the $0-10 \mathrm{~cm}$ depth. The SOC was fractionated into four fractions $\left(F_{1}, F_{1}, F_{2}\right.$ and $\left.F_{3}\right)$, adopting the chemical wet oxidation method based on increasing degrees of oxidation. The forest management caused a short-term change in the oxidizable fraction distribution of the SOC, which was reflected by a reduction of the most labile fractions.

Key words: organic matter, chemical fractionation, labile carbon.
\end{abstract}

Frações oxidáveis do carbono orgânico do solo em Caatinga arbórea submetida a manejo florestal

RESUMO: Umas das principais alternativas para a exploração racional dos recursos naturais da Caatinga é o manejo florestal sustentável. O carbono orgânico do solo (COS) e suas frações podem ser utilizados para avaliar o estado de conservação de ecossistemas florestais após intervenções antrópicas. Sendo assim, o objetivo deste estudo foi avaliar o efeito de curto prazo de diferentes práticas de manejo florestal sobre a distribuição das frações do COS em área de Caatinga arbórea, localizada na Floresta Nacional Contendas do Sincorá (BA). Foram avaliadas três práticas de manejo florestal (corte raso, corte seletivo por diâmetro e corte seletivo por espécie), utilizando como testemunha a Caatinga não manejada. As amostras de solo foram coletadas na profundidade de $0-10 \mathrm{~cm}$. O COS foi fracionado em quatro frações ( $F_{1}, F_{1}$, $F_{2}$ e $F_{3}$ ), adotando-se o método químico da oxidação úmida baseada em graus crescentes de oxidação. O manejo florestal ocasionou alteração em curto prazo na distribuição das frações oxidáveis do COS, que se refletiu em redução das frações mais lábeis.

Palavras-chave: matéria orgânica, fracionamento químico, carbono lábil.

The Caatinga is a characteristic biome of northeastern Brazil and extends through eight states in this region to the north of Minas Gerais state (GUERRA et al., 2014). Despite being a biome with representative biodiversity, its vegetation cover has been severely reduced by the indiscriminate exploitation of wood for fire wood and charcoal, and by the expansion of agricultural activities.

Among the actions that can be adopted for rationally exploiting natural resources of the Caatinga is sustainable forest management (FM), which is a set of interventions carried out in a forest area aiming sustainable production from the economic, environmental and social points of view (MINISTRY OF THE ENVIRONMENTMINISTÉRIO DO MEIO AMBIENTE - MMA, 2008).
Different forest management practices are usually adopted in the Caatinga biome with clear cutting and selective cutting by minimum diameter $(\leq 5 \mathrm{~cm})$ and by species (EMBRAPA, 2007; MMA, 2008) being the main practices. According to their potential for interference, such practices can lead to different levels of change in various components of the ecosystem, such as plant composition and soil attributes.

Among the soil chemical attributes, soil organic carbon (SOC) has been frequently used in assessing the conservation status and sustainability of forest ecosystems, since it exerts an influence on practically all soil processes from aggregation to nutrient supply to the plants (ZINN et al., 2002). However, minor changes in SOC may not 
be detected in the short term (CHAN et al., 2001; OLIVEIRA JÚNIOR et al., 2008). For this reason, studying the distribution of SOC in labile or stable fractions of soil organic matter (SOM) has been adopted which expresses differences in its storage time in the soil (BAYER et al., 2004), and shows changes in organic $\mathrm{C}$ quality before differences even occur in their total content (XAVIER et al., 2006; BARRETO et al., 2011).

Different methodologies are employed to fractionate SOC. The method proposed by CHAN et al. (2001) consists of chemical fractionation, which enables the separation of four fractions with increasing degrees of oxidation starting from an acid gradient (GUARESCHI et al., 2013). The first two fractions are considered to be of greater lability; and therefore, are usually more responsive to soil changes. The latter two fractions are less labile and are more related to compounds possessing higher chemical stability and molar mass (RANGEL et al., 2008).

In general, the oxidizable $\mathrm{C}$ fractions show that management systems favoring frequent additions of organic residues to the soil tend to have a higher $\mathrm{C}$ proportion in the labile fraction compared to the recalcitrant fraction (CHAN et al., 2001; BATISTA et al. al., 2014). Thus, knowledge on the distribution of SOC fractions in managed forest areas can enable evaluating changes in the dynamics of SOM compartments, and can help indicate the most appropriate forest management to maintain soil characteristics. However, studies related to this subject are still scarce, especially in Caatinga conditions.

In view of the above, this research had the objective of evaluating the short-term effect of different forest management practices on the distribution of SOC fractions in Caatinga forest submitted to different forest management practices.

The study was conducted in Contendas do Sincorá National Forest (FLONA), located in the municipality of Contendas do Sincorá, Bahia, which presents a flat relief and a hot semiarid climate (BSwh - Koppen classification). The FLONA covers an area of $11,216 \mathrm{ha}$ and has predominant vegetation classified as Caatinga vegetation/trees, with frequent species of Myracrodruon urundeuva, Schinopsis brasiliensis, Tabebuia sp., Aspidosperma pyrifolium and Cereus jamacarus (LIMA \& LIMA, 1998).

The study area in FLONA consists of four treatments which correspond to three types of forest management and one condition of no implemented management: (a) clear cutting (CC)-consisted of cutting and removing all trees; (b) selective cutting 1 (SC1)-cutting of all trees with diameter at breast height (DBH) of $5 \mathrm{~cm}$ or more; (c) selective cutting 2 (SC2)-selectively cuttingonly individuals of three species: Commiphora leptophloeos (Mart.) J.B. Gillett, Pseudobombax simplicifolium A. Robyns and Jatropha mollisima (Pohl.)Baill; and (d) Control (C) -unmanaged Caatinga, used as a reference.

Forest management was carried out in May 2015 by demarcating four plots of $20 \times 20 \mathrm{~m}$ $\left(400 \mathrm{~m}^{2}\right)$ for each treatment, totaling 16 plots, which were randomly chosen in the experimental area. Before management, the studied area was in a late successional stage, considering that the last interventions for wood extraction dated from the year of 1997 (MMA, 2006).

The soil of the experimental area belongs to the Eutrophic Red-Yellow Argisol Class (EMBRAPA, 2006), presents a loose texture (clay $=195 \mathrm{~g} \mathrm{~kg}^{-1}$, sand $=393 \mathrm{~g} \mathrm{~kg}^{-1}$ and silt $=412 \mathrm{~g} \mathrm{~kg}^{-1}$ ) and the following chemical characterization: $\mathrm{pH}=6.4$, $\mathrm{P}=3.5 \mathrm{mg} \mathrm{dm}^{-3}$, total $\mathrm{N}=1.5 \mathrm{~g} \mathrm{~kg}^{-1}, \mathrm{~K}^{+}=0.21 \mathrm{cmolc} \mathrm{dm}^{-3}$, $\mathrm{Ca}^{2+}=4.1 \mathrm{cmolc} \mathrm{dm}^{-3}, \mathrm{Mg}^{2+}=1.8 \mathrm{cmolc} \mathrm{dm}^{-3}, \mathrm{H}+\mathrm{Al}=1.9$ cmolc $\mathrm{dm}^{-3}$; according to methodologies described in EMBRAPA (2017).

Soil and litter samples were collected in May 2016. Ten (10) simple soil samples (depth $0-10 \mathrm{~cm}$ ) were collected in each experimental plot, which were collected to form a composite sample. The accumulated litter was collected using a square collector of $0.25 \mathrm{~m}^{2}(0.50 \mathrm{x} 0.50 \mathrm{~m})$, which was randomly cast once on the forest floor of each plot.

For determining the SOC fractions, the wet oxidation method proposed by CHAN et al. (2001) was adopted, along with modifications proposed by MENDONÇA \& MATOS (2005). The following were added to Erlenmeyer flasks: $0.5 \mathrm{~g}$ of sifted and macerated soil, $10 \mathrm{ml}$ of $0.167 \mathrm{~mol} \mathrm{~L}^{-1} \mathrm{~K}_{2} \mathrm{Cr}_{2} \mathrm{O}_{7}$ and concentrated sulfuric acid quantities of 2.5, 5, 10 and $20 \mathrm{ml}$. This fractionation allowed for preparing four acidic aqueous solutions resulting from the proportions of $0.25: 1,0.5: 1,1: 1$ and 2:1, corresponding to $3,6,9$ and $12 \mathrm{~mol} \mathrm{~L}^{-1}$ of $\mathrm{H}_{2} \mathrm{SO}_{4}$, respectively. Oxidation was carried out with an external heat source $\left(150^{\circ} \mathrm{C}\right)$ and titration of the obtained extracts was carried out with $0.5 \mathrm{~mol}$ solution of $\mathrm{Fe}\left(\mathrm{NH}_{4}\right)_{2}\left(\mathrm{SO}_{4}\right)_{2} \cdot \mathrm{H}_{2} \mathrm{O} \mathrm{L}{ }^{-1}$, using three drops of diphenylamine indicator.

Four fractions were then determined by comparing the $\mathrm{C}$ concentrations obtained with increasing degrees of oxidation: fraction 1' $\left(\mathrm{F}_{1}{ }^{\prime}\right)$, corresponding to the oxidizable $\mathrm{SOC}$ in a solution of $3 \mathrm{~mol} \mathrm{~L}^{-1}$; fraction $1\left(\mathrm{~F}_{1}\right)$, determined by the difference between the SOC obtained in the solutions of 6 and $3 \mathrm{~mol} \mathrm{~L}^{-1}$; fraction $2\left(\mathrm{~F}_{2}\right)$, obtained by the difference between SOC extracted in the solution of $9 \mathrm{~mol} \mathrm{~L}^{-1}$ 
and $6 \mathrm{~mol} \mathrm{~L}^{-1}$; and fraction $3\left(\mathrm{~F}_{3}\right)$, which is the residual organic $\mathrm{C}$ between the reactions with the 12 and $9 \mathrm{~mol}$ $\mathrm{L}^{-1}$ solutions.

Fractions were evaluated separately for better interpretation of the obtained results $\left(\mathrm{F}_{1}, \mathrm{~F}_{1}\right.$, $\mathrm{F}_{2}$ and $\left.\mathrm{F}_{3}\right)$ and also associated $\left(\mathrm{F}_{1}{ }^{\prime}+\mathrm{F}_{1}\right.$ and $\left.\mathrm{F}_{2}+\mathrm{F}_{3}\right)$, according to BARRETO et al. (2011), with the objective to verify differences not detected by the analysis of the isolated fractions. Thus, $\mathrm{F}_{1}{ }^{\prime}+\mathrm{F}_{1}$ was considered to consist of more easily oxidizable $\mathrm{C}$ compounds, and $\mathrm{F}_{2}+\mathrm{F}_{3}$ constituted of more resistant organic compounds.

The relative participation of the oxidizable fractions in relation to the SOC and to the ratio $\left(\mathrm{F}_{1}{ }^{\prime}+\mathrm{F}_{1}\right):\left(\mathrm{F}_{2}+\mathrm{F}_{3}\right)$, which represents the predominant form of $\mathrm{C}$ in the soil. Values of this ratio greater than one indicate a predominance of $\mathrm{C}$ in more labile forms, while smaller values demonstrate that more recalcitrant forms of $\mathrm{C}$ are in greater proportion in the soil.

Data were analyzed for homogeneity and normality by the Cochran and Lilliefors tests. Since the data were parametric, means were compared by the Dunnet test at a 5\% significance level, and the analysis of variance was performed according to a completely randomized design, presenting a significant result in the F-test $(\mathrm{P}<0.05)$. In addition, Pearson correlations $(\alpha=5 \%)$ were established between litter, SOC and carbon fractions. Statistical analyzes were performed using the $\mathrm{SAEG}^{\circledR}$ v.9.1 software program.

Soil organic carbon did not vary among treatments (mean of $16.1 \mathrm{~g} \mathrm{~kg}^{-1}$ ) (Table 1), demonstrating that the different management did not lead to short-term changes in the total organic matter content in the soil. According to BAYER et al. (2004), changes in SOM usually occur slowly, requiring medium- and long-term studies to better detect variations.

The highest accumulations of oxidizable $\mathrm{C}$ were observed in the very labile fraction $\left(\mathrm{F}_{1}{ }^{\prime}\right)$ in all treatments (Table 1). However, this fraction was not differentiated between treatments, being between 5.7 and $6.2 \mathrm{~g} \mathrm{~kg}^{-1}$ and representing an average of $38 \%$ of the SOC content (Table 1). These results are in agreement with ROSSET et al. (2016), who observed that $\mathrm{F}_{1}$, contributed with about $32 \%$ of the total organic $\mathrm{C}$ in soils under native forest and pasture $(0-5 \mathrm{~cm}$ layer $)$.

Table 1 - Total organic carbon, oxidizable fractions of organic carbon and their relative contributions in soil under Caatinga trees submitted to forest management.

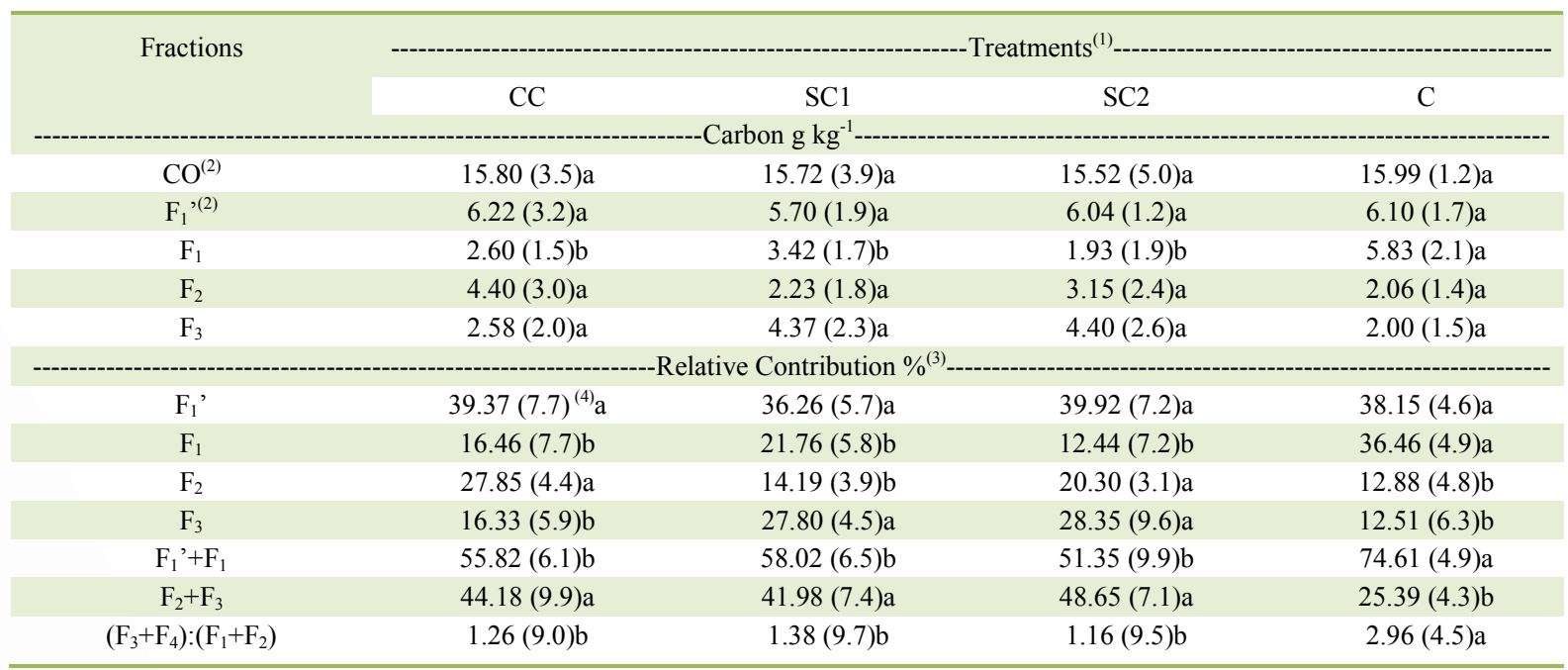

${ }^{(1)} \mathrm{CC}$ - Clear cutting; SC1 -Selective cutting 1; SC2 -Selective cutting 2; C-Control; ${ }^{(2)} \mathrm{CO}$-Total soil organic carbon; $\mathrm{F}_{1}$ - $-\mathrm{C}$ oxidized by $\mathrm{K}_{2} \mathrm{Cr}_{2} \mathrm{O}_{7}$ in acid medium of 3 molH$_{2} \mathrm{SO}_{4} \mathrm{~L}^{-1} ; \mathrm{F}_{1}$-difference of $\mathrm{C}$ oxidized by $\mathrm{K}_{2} \mathrm{Cr}_{2} \mathrm{O}_{7}$ in acid medium of 6 and 3 mol $\mathrm{H}_{2} \mathrm{SO}_{4} \mathrm{~L}^{-1}$; $\mathrm{F}_{2}$ differenceofC oxidized by $\mathrm{K}_{2} \mathrm{Cr}_{2} \mathrm{O}_{7}$ in acid medium of 9 and $6 \mathrm{~mol} \mathrm{H}_{2} \mathrm{SO}_{4} \mathrm{~L}^{-1} ; \mathrm{F}_{3}$ - difference of $\mathrm{C}$ oxidized by $\mathrm{K}_{2} \mathrm{Cr}_{2} \mathrm{O}_{7}$ in acid medium of 12 and $9 \mathrm{molH}_{2} \mathrm{SO}_{4} \mathrm{~L}^{-1} ; \mathrm{F}_{1}{ }^{\prime}+\mathrm{F}_{1}$-labile fractions; $\mathrm{F}_{2}+\mathrm{F}_{3}-$ recalcitrant fractions. ${ }^{(3)}$ Relative contribution of each of the oxidizable $\mathrm{C}$ fractions in relation to the total soil organic $\mathrm{C}$. ${ }^{(4)}$ Values in parentheses refer to the standard deviation of the mean $(\mathrm{n}=8)$. The same lowercase letters in the line that compare the $\mathrm{C}$ content and the percentages of each fraction associated with $\mathrm{CO}$ between the treatments did not differ among them by the Dunnet test at $5 \%$. 
Conversely, the labile carbon fraction $\left(\mathrm{F}_{1}\right)$ showed variation between the treatments (Table 1), being higher in the control $\left(5.83 \mathrm{~g} \mathrm{~kg}^{-1}\right)$ in relation to the treatments $\left(2.65 \mathrm{~g} \mathrm{~kg}^{-1}\right)$ (Table 1). This result suggested that the absence of intervention in the vegetation favored the $\mathrm{C}$ accumulation in this fraction, possibly due to the maintenance of the continuous contribution of litter. The participation of $\mathrm{F}_{1}$ in SOC was $37 \%$ in the control and $17 \%$ in the other treatments. In studying the Caatinga area in Ceará, MAIA et al. (2007) found a $F_{1}$ contribution close to that observed in the control condition in the present study (37\%).

The fractions $\mathrm{F}_{1}$, and $\mathrm{F}_{1}$ together $\left(\mathrm{F}_{1}{ }^{\prime}+\right.$ $\mathrm{F}_{1}$ ) represented $75 \%$ of the SOC in the control and approximately $55 \%$ in the different treatments (Table 1). Several studies in soils under native and planted forests also reported that the oxidizable fractions of greater lability constituted a greater proportion of the SOC, and when associated they corresponded to values of higher than $40 \%$ (MAIA et al., 2007; BARRETO et al., 2011; ROSSET et al., 2016).

The greater contribution of $F_{1}{ }^{\prime}+F_{1}$ in the unmanaged Caatinga showed that all the adopted practices promoted a reduction in $\mathrm{C}$ accumulation in greater lability fractions. It is probable that this result is due to the partial or total removal of the vegetation in the managed areas, which caused a decrease in the leaf contribution and an increased accumulation of more recalcitrant residues on the soil (crop residues). This explanation is corroborated by the litter composition accumulated in the studied treatments, which showed a greater participation of branches ( 45 to $73 \%$ ) and lower leaves (15 to $35 \%$ ) in areas submitted to management in relation to the control (branches $=35 \%$; leaves $>55 \%$ ).

In this sense, significant positive correlations were reported between $F_{1}$ fraction and leaf litter stock $(r=0.61, P<0.05)$ and between $\mathrm{F}_{2}$ fraction and total litter accumulation $(\mathrm{r}=0.65$ and $\mathrm{r}=0.68, \mathrm{P}<0.05$, respectively). Wood materials such as branches usually present high lignin contents; a compound that is highly resistant to decomposition, and which favors higher $\mathrm{C}$ accumulation in the slightly labile fraction (SWIFT et al., 1979). Thus, these correlations suggested that because the litter components present variations in their degradability degree, they would be favoring an accumulation of moderately labile or slightly labile forms of $\mathrm{C}$ in the soil.

In addition to the quality of the plant residues deposited in the soil, reductions in the more labile SOC fractions can also be related to greater exposure of the $\mathrm{C}$ fractions to the decomposing microorganisms or to an elevation in soil temperature and moisture (CASTRO FILHO et al., 1991).

The moderately labile $\left(\mathrm{F}_{2}\right)$ and slightly labile $\left(\mathrm{F}_{3}\right)$ fractions did not vary between treatments (Table 1). This absence in variation can be related to the fact that this study was carried out in a short period of time after the forest management (only one year), which would not have been enough to express differences in the less labile fractions, since these have a greater soil stability characteristic (RANGEL et al., 2008). Together, the $\mathrm{F}_{2}+\mathrm{F}_{3}$ fractions represented an average of $40 \%$ of total SOC. These results are similar to those of GUARESCHI et al. (2013), who observed that $\mathrm{F}_{2}+\mathrm{F}_{3}$ contributed close to $31 \%$ of SOC in a native Cerrado area.

The ratio $\left(\mathrm{F}_{1}{ }^{\prime}+\mathrm{F}_{1}\right):\left(\mathrm{F}_{2}+\mathrm{F}_{3}\right)$ was higher in the unmanaged Caatinga (2.94) when compared to the other treatments (mean of 1.23) (Table 1). This relation was positively correlated with the leaf litter stock $(\mathrm{r}=0.71, \mathrm{P}<0.01)$. These results are in agreement with those discussed previously, indicating that the increase in the recalcitrant accumulated litter level of the managed areas promotes a change in the quality of organic $\mathrm{C}$ accumulated in the soil.

The results obtained in this research revealed that forest management triggers short-term changes in the quality of SOM regardless of the type of practice adopted, which caused a decrease in the SOC levels of the most labile fractions. These fractions corresponded to $75 \%$ of the SOC in the unmanaged areas, and $55 \%$ in the managed areas.

\section{ACKNOWLEDGEMENTS}

To the Conselho Nacional de Desenvolvimento Científico e Tecnológico-CNPq, for granting financial support to the project.

\section{DECLARATION OF CONFLICTING OF INTERESTS}

The authors declare no conflict of interest. The founding sponsors had no role in the design of the study; in the collection, analyses, or interpretation of data, in the writing of the manuscript, and in the decision to publish the results.

\section{AUTHORS' CONTRIBUTIONS}

SGMB conducted the experiment and prepared the initial version of the manuscript. PABBG conceived, designed and supervised the research. AP participated in the design of the project. DLM and WCAB performed laboratory analyzes. All authors critically reviewed the manuscript and approved the final version.

Ciência Rural, v.48, n.10, 2018. 


\section{REFERENCES}

BARRETO, P.A.B. et al (Two authors or more). Distribution of oxidizable organic $\mathrm{C}$ fractions in soils under cacao agroforestry systems in Southern Bahia, Brazil. Agroforestry Systems, v.81, p.213-220, 2011. Available from: <http://dx.doi.org/10.1007/s10457-010-9300-4>. Accessed: Mar. 21, 2016. doi: 10.1007/s10457-010-9300-4.

BATISTA, I. et al (Two authors or more). Oxidizable fractions of total organic carbon and soil macrofauna in a crop-live stock integration system. Revista Brasileira de Ciência do Solo, v.38, p.797-809, 2014. Available from: <http://dx.doi.org/10.1590/S010006832014000300011>. Accessed: Jun. 12, 2016. doi:10.1590/S010006832014000300011 .

BAYER, C. et al (Two authors or more). Carbon storage in labile fractions of soil organic matter in a tropical no-tillage Oxisol Pesquisa Agropecuária Brasileira, v.39, p.677-683, 2004. Available from: $\quad<$ http://dx.doi.org/10.1590/S0100-204X2004000700009>. Accessed: Jun. 13, 2016. doi: 10.1590/S0100-204X2004000700009.

CASTRO FILHO, C. et al (Two authors or more). Tillage methods and soil and water conservation in southern Brazil. Soil Tillage, Amsterdam, v.20, p.271-283, 1991. Available from: $<$ http://dx.doi. org/10.1016/0167-1987(91)90043-W>. Accessed: Jul. 18, 2016. doi: 10.1016/0167-1987(91)90043-W.

CHAN, K.Y. et al. (Two authors or more). Oxidizible organic carbon fractions and soil quality changes in an oxic paleustalf under different pasture leys. Soil Science, v.166, p.61-67, 2001.

EMPRESA BRASILEIRA DE PESQUISA AGROPECUÁRIA - EMBRAPA. Preservação da Caatinga, Embrapa Semi-Árido. Brasília, DF. (ABC da Agricultura Familiar, 16). 2007. 39 p.

EMPRESA BRASILEIRA DE PESQUISA AGROPECUÁRIA EMBRAPA. Centro Nacional de Pesquisa de Solos. Manual de métodos de análise de solo. 3.ed. rev. Eampl. Brasília, 2017. Online. Available from: $<$ https://www.infoteca.cnptia.embrapa.br/infoteca/ bitstream/doc/1088695/1/Pt2Cap17RelacoesmolecularesKieKr. pdf>. Accessed: Aug. 04, 2017.

EMPRESA BRASILEIRA DE PESQUISA AGROPECUÁRIA - EMBRAPA. Centro Nacional de Pesquisa de Solos (Rio de Janeiro). Sistema Brasileiro de Classificação de solos. 2. ed. Rio de Janeiro, 2006. 306 p.

GUARESCHI, R.F. et al. (Two authors or more). Oxidizable carbon fractions in Red Latosol under different management systems. Revista Ciência Agronômica, v.44, p.242-250, 2013. Available from: <http:// dx.doi.org/10.1590/S1806-66902013000200005>. Acessed: Jun. 13, 2016. doi: 10.1590/S1806-66902013000200005.

GUERRA, A.M.N. et al. (Two authors or more). Phytosociological study of two environments in the Caatinga of the Moacir Lucena Settlement, Apodi - RN - BRAZIL. Revista Verde de Agroecologia e Desenvolvimento Sustentável, v.9, p.141-150, 2014. Available from: $<$ https://www.gvaa.com.br/revista/index.php/RVADS/article/ view/2214>. Accessed: May 15, 2016
MAIA, S.M.F. et al. (Two authors or more). Organic carbon pools in a Luvisol under agroforestry and conventional farming systems in the semi-arid region of Ceará, Brazil. Agroforestry Systems, v.71, p.127-138, 2007. Available from: <http://dx.doi.org/10.1007/ s10457-007-9063-8>. Accessed: Apr. 13, 2016. doi: 10.1007/ s10457-007-9063-8.

MENDONÇA, E.S.; MATOS, E.S. Matéria orgânica do solo: Métodos de análises, Viçosa: UFV, 2005. 108 p.

MINISTÉRIO DO MEIO AMBIENTE - MMA. Plano de Manejo da Floresta Nacional Contendas do Sincorá, 2006. 132 p. Online. Available from: <http://www.icmbio.gov.br>. Accessed: May 15, 2017.

MINISTÉRIO DO MEIO AMBIENTE - MMA. Secretaria de Biodiversidade e Florestas. Manejo sustentável dos recursos florestais da Caatinga. Programa Nacional de Florestas. Unidade de Apoio do PNF no Nordeste. Natal: MMA, 2008. 28p.

OLIVEIRA JÚNIOR, A.C. et al. (Two authors or more). Chemical indicators of the quality of organic matter of soil from the Rio das Mortes watershed under different coffee plant managements. Química Nova, v. 31, n. 7, p.1733-1737, 2008. Available from: $<\mathrm{http}$ ://dx.doi.org/10.1590/S0100-40422008000700026>. Accessed: Jun. 10, 2016. doi: 10.1590/S0100-40422008000700026.

RANGEL, O.J.P. et al. (Two authors or more). Oxidizible organic carbon fractions in a latosol cultivated with coffee at different planting spacings. Ciência e Agrotecnologia, v.32, p.429437, 2008. Available from: <http://dx.doi.org/10.1590/S141370542008000200013>. Accessed: Jun. 10, 2016. doi: 10.1590/ S1413-70542008000200013.

ROSSET, J.S. et al. (Two authors or more). Chemical and oxidizable fractions of soil organic matter under different management systems in an Oxisol. Pesquisa Agropecuária Brasileira, v.51, n.9, p.15291538, 2016. Available from: <http://dx.doi.org/10.1590/S0100204X2016000900052>. Accessed: Jan. 30, 2017. doi: 10.1590/ S0100-204X2016000900052.

SWIFT, M.J. et al. (Two authors or more). The influence of resource quality on decomposition processes. In: Decomposition in terrestrial ecosystems. Berkeley, University of California Press, 1979, p.118-166.

XAVIER, F.A.S. et al. (Two authors or more). Microbial biomass and light organic matter in soils under organic and conventional systems in the Chapada da Ibiapaba - CE, Brazil. Revista Brasileira de Ciência do Solo, v.30, p.247-258, 2006. Available from: <http:// dx.doi.org/10.1590/S0100-06832006000200006>. Accessed: Feb. 08, 2017. doi: 10.1590/S0100-06832006000200006.

ZINN, Y. L. et al. (Two authors or more). Soil organic carbon as affected by afforestation with Eucalyptus and Pinus in the Cerrado region of Brazil. Forest Forest Ecology and Management, v.166, p.285-294, 2002. Available from: <http://dx.doi.org/10.1016/ S0378-1127(01)00682-X>. Accessed: May 15, 2017. doi: 10.1016/ S0378-1127(01)00682-X 